\title{
USE OF ELISA EMPLOYING HOMOLOGOUS AND HETEROLOGOUS ANTIGENS FOR THE DETECTION OF IgG AND SUBCLASSES (IgG1 AND IgG2) IN THE DIAGNOSIS OF CANINE VISCERAL LEISHMANIASIS
}

Flávia Coelho RIBEIRO(1), Armando de O. SCHUBACH(1), Eliame MOUTA-CONFORT(1), Tânia M.V. PACHECO(2), Maria de Fátima MADEIRA(1), Luiz Cláudio de Souza ABBOUD(3), Carla de Oliveira HONSE(2), Andreia Silva ALVES(1) \& Mauro C.A. MARZOCHI(1)

\begin{abstract}
SUMMARY
Indirect immunofluorescence is the method recommended for the diagnosis of visceral leishmanisis in dogs, however, the accuracy of this technique is low and its use on a large scale is limited. Since ELISA does not present these limitations, this technique might be an option for the detection of IgG or specific IgG1 and IgG2 subclasses. Canine ehrlichiosis is an important differential diagnosis of American Visceral Leishmaniasis (AVL). The present study compared ELISA using Leishmania chagasi and Leishmania braziliensis antigen for the detection of anti-Leishmania IgG and subclasses in serum samples from 37 dogs naturally infected with $L$. chagasi (AVL) and in samples from four dogs co-infected with L. braziliensis and L. chagasi (CI). The occurrence of cross-reactivity was investigated in control serum samples of 17 healthy dogs (HC) and 35 infected with Ehrlichia canis (EC). The mean optical density obtained for the detection of IgG was significantly higher when L. chagasi antigen was used, and was also higher in subgroup VLs (symptomatic) compared to subgroup Vla (asymptomatic). The correlation between IgG and IgG1 was low. The present results suggest that IgG ELISA using homologous antigen yields the best results, permitting the diagnosis of asymptomatic L. chagasi infection and the discrimination between cases of AVL and ehrlichiosis in dogs.
\end{abstract}

KEYWORDS: American visceral leishmaniasis; Dog; IgG subclasses; L. (V.). braziliensis, L. (L.) chagasi.

\section{INTRODUCTION}

Leishmania (Leishmania) chagasi is a viscerotropic parasite of lymphoid organs and the causative agent of American visceral leishmaniasis (AVL), also known as Kala-azar ${ }^{1}$. AVL is found in various American countries. In Brazil, AVL presents a high incidence in urban and periurban areas ${ }^{39}$. In the municipality of Rio de Janeiro, AVL emerged at the end of the 1970s in periurban areas of the northern zone of the city, especially at the hillside of the Pedra Branca massif ${ }^{32}$. The domestic dog (Canis familiaris) is the main reservoir of AVL due to intense parasitism of healthy skin and viscera since the onset of infection ${ }^{15,28,32,41,45}$. It is believed that most infected dogs do not develop clinical signs and remain asymptomatic for variable periods of time ${ }^{19,32}$. In Brazil, AVL requires obligatory notification and control programs involve the treatment of human cases, control of the insect vector, and euthanasia of seropositive infected dogs. The Brazilian Ministry of Health recommends serological testing by indirect immunofluorescence (IIF), with antibody titers of 1:40 or higher being used as a criterion for the culling of $\operatorname{dog} \mathrm{s}^{39}$.

The control measures adopted in Brazil are a matter of discussion since new AVL foci continue to appear in the country ${ }^{13}$. The relative inefficiency of these measures has contributed to the emergence of AVL, especially because of the underestimated seroprevalence of canine infection provided by the IIF test ${ }^{51}$. Some authors suggest that a highly sensitive test, combined with rapid culling of the dogs, is necessary for a significant reduction in the transmission of the disease and effective control $^{11,16}$. According to BRAGA et al. ${ }^{8}$, only $35.4 \%$ of infected dogs identified by enzyme-linked immunosorbent assay (ELISA) would be detected by IIF. As a consequence, some infected dogs would not be identified during control actions and would remain in endemic areas, a fact facilitating propagation of the infection. In addition to its lower sensitivity and specificity when compared to ELISA ${ }^{30}$, IIF is more time consuming and requires trained professionals ${ }^{5,17}$. The rapidity and possibility of automation of ELISA are additional advantages that favor its use on a large scale.

Once clinical signals are installed, AVL should be differentiated from ehrlichiosis, lymphosarcoma, myeloma, seborrhea, pemphigus and systemic fungal infections, as well as from other diseases causing proliferation of the reticuloendothelial system ${ }^{23}$. Ehrlichiosis is a disease caused by the rickettsia Ehrlichia canis, which primarily parasitizes cytoplasmic vacuoles of monocytes and granulocytes ${ }^{47,55}$, causing a

(1) Laboratório de Vigilância em Leishmanioses, Instituto de Pesquisa Clínica Evandro Chagas, Fundação Oswaldo Cruz (FIOCRUZ), Rio de Janeiro, RJ, Brasil.

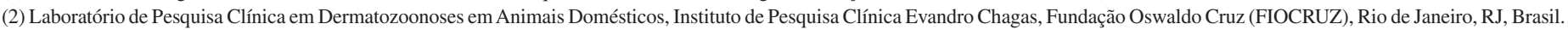
(3) Instituto Municipal de Medicina Veterinária Jorge Vaitsman.

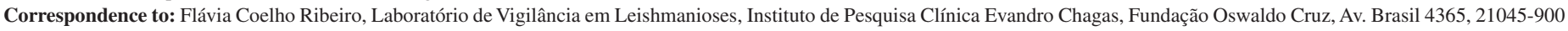
Rio de Janeiro, RJ, Brasil. Tel:+55 213865 9594; +55 2138659541 or +55 213865 9785. E-mail: fcribeiro@ fiocruz.br 


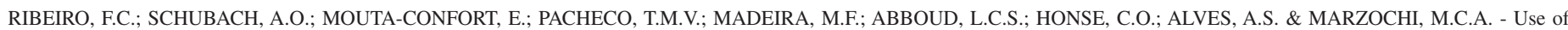
ELISA employing homologous and heterologous antigens for the detection of IgG and subclasses (IgG1 and IgG2) in the diagnosis of canine visceral leishmaniasis. Rev. Inst. Med. Trop. Sao Paulo, 53(5): 283-9, 2011

potentially fatal multisystemic infection that is characterized by clinical and hematological anomalies similar to those observed in AVL, including fever, lymphadenopathy, anorexia, lethargy and thrombocytopenia ${ }^{31,36,42}$. Ehrlichia canis presents a wide geographic distribution and mainly occurs in tropical and subtropical areas. In Rio de Janeiro, ehrlichiosis is one of the most common causes of visits to veterinary clinicians, with a mean prevalence of the disease of $26.8 \%$ in thrombocytopenic $\operatorname{dogs}^{27}$. Despite the clinical and epidemiological similarity to AVL, there is no indication for euthanasia of dogs as a public health measure. Thus, the test used for the serodiagnosis of canine AVL should be able to differentiate the two infections ${ }^{48}$.

The IgG subclasses, whose expression depends on the nature of the antigen and antigenic stimulus, are involved in different biological activities. In dogs, four IgG subclasses have been defined ${ }^{33,34,35}$, which can be applied to the diagnosis of infectious diseases, including leishmaniasis ${ }^{24,52}$. The study of IgG subclasses in canine AVL might have a practical application both to the diagnosis and to the development of control strategies ${ }^{50}$.

In the present study, we compared the results of ELISA using L. (L.) chagasi (homologous) and L. (V.) braziliensis (heterologous) antigen for the detection of anti-Leishmania $\mathrm{IgG}, \mathrm{IgG} 1$ and $\mathrm{IgG} 2$ antibodies for the diagnosis of symptomatic and asymptomatic infection of dogs with $L$. (L.) chagasi and for the possible discrimination with cases of canine ehrlichiosis.

\section{MATERIAL AND METHODS}

Population and biological samples: Serum samples obtained from 93 domestic dogs were tested for leishmaniasis by total IgG and subclass IgG1 and IgG2 ELISA. The animals were classified into three well-defined groups: group VL $(n=37)$ included animals infected with $L$. (L.) chagasi. This group was subdivided into two subgroups: asymptomatic animals (VLa, $\mathrm{n}=12$ ), and symptomatic animals (VLs, $\mathrm{n}$ $=25$ ) that presented two or more clinical signs of AVL: skin ulcerations, desquamation, adenitis, weight loss, alopecia, hepatosplenomegaly, onychogryphosis, anemia, fever, apathy, and keratoconjunctivitis. Group CI $(\mathrm{n}=4)$ consisted of dogs co-infected with $L$. (L.) chagasi and $L$. (V.) braziliensis. All dogs included in groups VL and CI were from AVLendemic areas in the municipality of Rio de Janeiro, tested seropositive by IIF, and were euthanized according to the municipal zoonosis control program. In all animals of the two groups, the diagnosis of infection was established by isolation of Leishmania from cultured viscera or skin and species characterization by isoenzyme electrophoresis ${ }^{29}$.

The control group consisted of $52 \mathrm{dogs}$ subdivided into two subgroups: healthy controls $(\mathrm{HC}, \mathrm{n}=17)$ and E. canis infected controls $(\mathrm{EC}, \mathrm{n}=35)$. Group HC included healthy dogs with no clinical alterations and normal blood count and biochemical parameters (protein, globulin, glutamate-oxaloacetate transaminase/aspartate aminotransferase (GOT/AST), glutamate-pyruvate transaminase/ alanine aminotransferase (GPT/ALT), albumin, blood urea and creatinine) that lived outside AVL endemic areas and had a negative parasitological diagnosis of canine ehrlichiosis. Group EC included dogs with two or more clinical signs compatible with AVL but that lived outside AVL endemic areas and in which E. canis was visualized by direct parasitological examination of blood smears.
Indirect immunofluorescence: IIF for the detection of antiLeishmania $\mathrm{IgG}$ was performed according to manufacturer instructions (Biomanguinhos/FIOCRUZ kit, Rio de Janeiro, Brazil). Titers $\geq 1: 40$ were considered to be positive. Serum samples of dogs from the VL and CI groups (tested within the leishmaniasis control program as inclusion criterion for this study) were retested and serum samples of dogs from the $\mathrm{HC}$ and $\mathrm{EC}$ groups were tested for the first time.

Antigens used for ELISA: Partially soluble fractions of promastigote forms of L. (V.) braziliensis (MHOM/BR/75/M2903) and L. (L.) chagasi (MHOM/BR/74/PP75) obtained during the stationary phase of growth according to the protocol of RIBEIRO et al. ${ }^{46}$ were used as antigens for ELISA.

ELISA: ELISA for the detection of anti-Leishmania IgG, IgG1 and IgG2 was carried out according to the method of VOLLER et al $^{54}$ using $L$. (V.) braziliensis or L. $(L$.) chagasi antigen. The cut-off point was determined as described by RIBEIRO et $a l .{ }^{46}$. Briefly, the antigens were diluted as follows: L. (V.) braziliensis at concentrations of $5 \mu \mathrm{g} / \mathrm{mL}$ for the detection of $\operatorname{IgG}$ and $7.5 \mu \mathrm{g} / \mathrm{mL}$ for the detection of $\mathrm{IgG} 1$ and $\operatorname{IgG} 2$, and $L$. (L.) chagasi at concentrations of $10 \mu \mathrm{g} / \mathrm{mL}$ for the detection of IgG and IgG1 and $2.5 \mu \mathrm{g} / \mathrm{mL}$ for the detection of $\mathrm{IgG} 2$. Next, the serum samples were diluted 1:20 for $L$. (V.) braziliensis and 1:100 for $L$. (L.) chagasi antigen in a solution of $1 \%$ skim milk (Molico-Nestléß) in PBS/0.05\% Tween 20 $(\mathrm{v} / \mathrm{v})$. The plates were then incubated with peroxidase-conjugated anti-dog IgG (Sigma Chemical Co., St. Louis, MO, USA) and anti-dog IgG1 and IgG2 immunoglobulins (Bethyl Laboratories, Inc., Montgomery, TX, USA) at dilutions of $1: 40,000,1: 10,000$ and 1:30,000 for reactions with $L$. (V.) braziliensis antigen and dilutions of 1:20,000, 1:5,000 and 1:30,000 for reactions with $L$. (L.) chagasi antigen, respectively.

Different concentrations of antigen and conjugates used were set independently for each class and subclass of IgG, using criteria for choosing the lowest concentration of antigen and greater dilution of the conjugate, which maximized the parameters of sensitivity and specificity of the test.

Statistical analysis: The cut-off was determined from the ROC curves calculated with the MedCalc statistical program (version 8.2.0.2). The nonparametric Spearman test was used for the comparison of the position and variation in optical density (OD) and their eventual correlation since the data did not follow a normal distribution. Mean OD values were compared by the paired Student t-test using the SPSS version 11.0 statistical software package. Differences at $\mathrm{p}<0.05$ were considered to be significant.

\section{RESULTS}

Indirect immunofluorescence: All sera from dogs of group VL reacted at different dilutions: four $(10.8 \%)$ at a titer of $1: 80$, seven $(18.9 \%)$ at titers ranging from $1: 160$ to $1: 320$, and $26(70.3 \%)$ at a titer $\geq 1: 640$. In the mixed infection group $(\mathrm{CI})$, one serum sample reacted at a titer of $1: 160$ and three at a titer of 1:320. The sera of one dog in the HC group $(5.9 \%)$ and two dogs $(5.7 \%)$ in the EC group reacted at a titer of 1:40.

\section{ELISA}

Correlation between ODs in the different reactions: In all groups, high and significant Spearman correlations were observed between the 


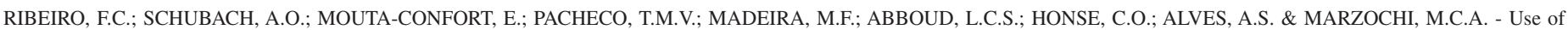

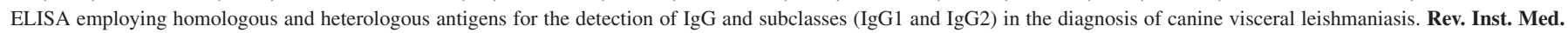
Trop. Sao Paulo, 53(5): 283-9, 2011.

IgG and IgG2 values for all sera analyzed when L. (V.) braziliensis ( $r=$ $0.86, p<0.01)$ or $L$. (L.) chagasi antigen $(r=0.95, p<0.01)$ was used, respectively. In contrast, the correlation between $\operatorname{IgG}$ and $\operatorname{IgG} 1$ was low but significant when $L$. (V.) braziliensis $(r=0.49, p<0.01)$ and $L$. (L.) chagasi antigen $(r=0.45, p<0.01)$ was used.

In group VL, no significant correlation for the detection of IgG1 was observed between symptomatic and asymptomatic animals with either $L$. (V.) braziliensis $(r=0.12, p=.35)$ or $L$. (L.) chagasi $(r=0.09$, $p=0.46)$ antigen.

Determination of the cut-off: The determination of the cut-off was established by ROC curve, considering all sera from infected (LVs, VLA, IC) and uninfected animals (HC and EC), choosing the point on the curve that maximizes sensitivity and specificity provided by the program MedCalc (version 8.2.0.2).

The cut-off value that permitted the best discrimination between the infected groups (VL and CI) and control animals (HC and EC) was determined from the respective ROC curves (Fig. 1 and 2) plotted for each ELISA reaction (IgG, IgG1 and $\mathrm{IgG} 2$ ) obtained with the $L$. (V.) braziliensis and $L$. (L.) chagasi antigens. The following cut-off values were obtained for the IgG, IgG1 and IgG2 reactions: $0.212,0.081$ and 0.347 for $L$. (V.) braziliensis antigen, and $0.32,0.085$ and 0.15 for $L$. $(L$. chagasi antigen, respectively.

Comparison of the area under the ROC curve: No significant differences were observed when comparing the areas under the curve (AUC) for the detection of $\mathrm{IgG}$ and $\mathrm{IgG} 2$ using either $L$. (V.) braziliensis or $L$. (L.) chagasi as antigen ( $p=0.85)$ (Table 1$)$. Significantly different AUCs $(p<0.05)$ were observed when comparing IgG and IgG2 with IgG1 for both $L .(V$.$) braziliensis and L$. (L.) chagasi antigen, respectively.

OD values: The following mean $\mathrm{OD}$ values and their standard deviations were obtained for the VL group: $0.811 \pm 0.142$ for IgG, 0.124 \pm 0.061 for $\mathrm{IgG} 1$ and $1.429 \pm 0.426$ for $\operatorname{IgG} 2$ when $L$. (V.) braziliensis antigen was used, respectively, and $1.728 \pm 0.426,0.239 \pm 0.253$ and

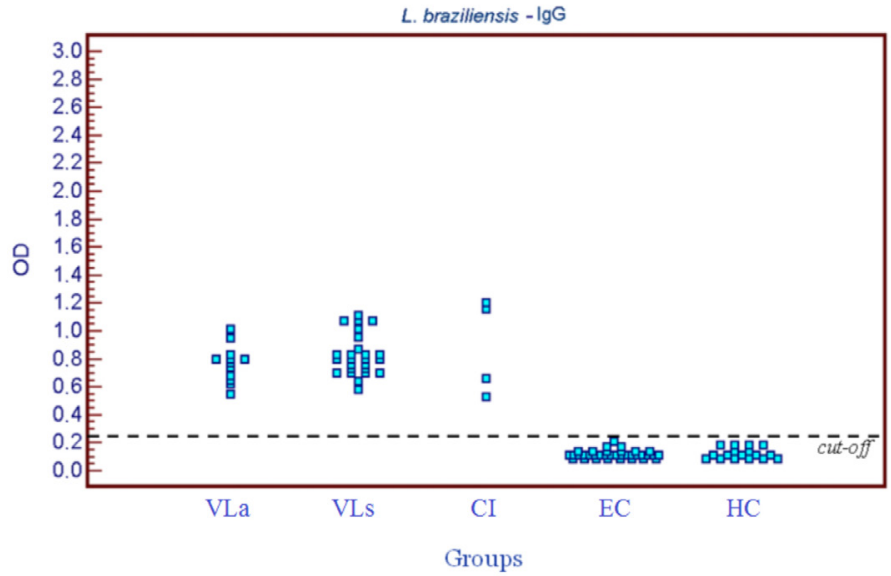

Fig. 1 - Distribution of OD values in ELISA reactions (IgG) using L. (V.) braziliensis antigen obtained for the visceral leishmaniasis group (VL) (symptomatic subgroup, VLs, and asymptomatic subgroup, VLa), group co-infected with $L$. (L.) chagasi and L. (V.) braziliensis (CI), and control group (healthy subgroup, HC, and ehrlichiosis subgroup, EC).

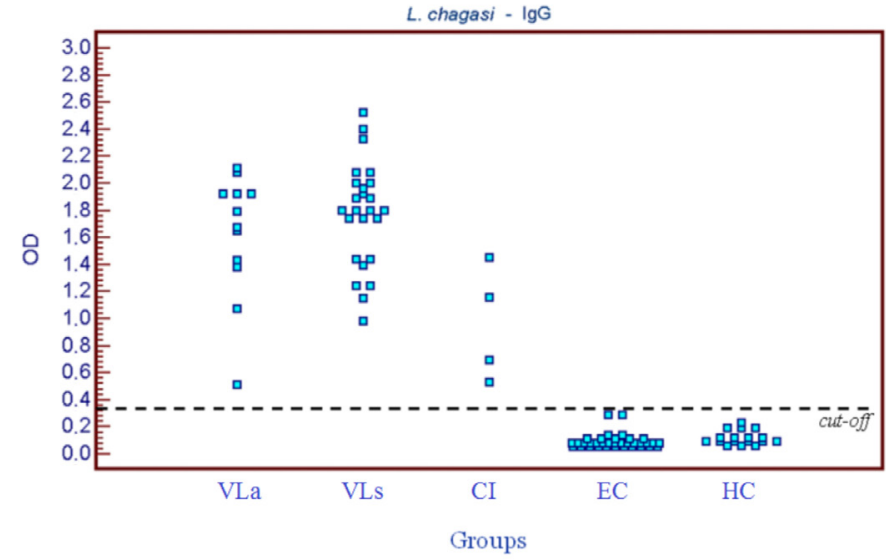

Fig. 2 - Distribution of OD values in ELISA reactions (IgG) using L. (L.) chagasi antigen obtained for the visceral leishmaniasis group (VL) (symptomatic subgroup, VLs, and asymptomatic subgroup, VLa), group co-infected with $L$. (L.) chagasi and L. (V.) braziliensis (CI), and control group (healthy subgroup, HC, and ehrlichiosis subgroup, EC).

Table 1

Area under the curve values for IgG, IgG1 and $\mathrm{IgG} 2$ for antigens of L. braziliensis and L. chagasi.

\begin{tabular}{cccc}
\hline L. braziliensis & $\begin{array}{c}\text { Area under the } \\
\text { curve }\end{array}$ & L. chagasi & $\begin{array}{c}\text { Area under the } \\
\text { curve }\end{array}$ \\
\hline IgG & 1,000 & IgG & 1,000 \\
IgG1 & 0.913 & IgG1 & 0.858 \\
IgG2 & 1,000 & IgG2 & 1,000 \\
\hline
\end{tabular}

$1.177 \pm 0.337$ when $L$. (L.) chagasi antigen was used. The mean OD values obtained for the detection of $\operatorname{IgG}$ (Fig.1 and 2) and IgG1 were significantly higher when $L$. (L.) chagasi was used as antigen $(p<0.01)$.

The seroprevalence of IgG and IgG2 was $100 \%$ in both symptomatic and asymptomatic dogs, irrespective of the antigen used. When using $L$. (L.) chagasi as antigen to compare symptomatic and asymptomatic dogs, no significant difference was found in the mean OD values obtained for the detection of $\operatorname{IgG}(1.778 \pm 0.387$ and $1.622 \pm 0.466, p=0.20$, respectively) (Fig. 1 and 2$), \operatorname{IgG} 1(0.252 \pm 0.287$ and $0.212 \pm 0.166$, $p=0.65)$ or $\operatorname{IgG} 2(1.244 \pm 0.281$ and $1.037 \pm 0.410, p=0.08)$.

The seroprevalence of IgG1 did not differ significantly between symptomatic and asymptomatic dogs when L. (V.) braziliensis $(84 \%$ versus $75 \%, p=0.84$ ) or $L$. (L.) chagasi antigen ( $88 \%$ versus $83.3 \%$, $p=0.90)$ was used.

In the CI group, mean OD values and their standard deviations for the detection of $\operatorname{IgG}, \operatorname{IgG} 1$ and $\operatorname{IgG} 2$ were, respectively: $0.886 \pm 0.342$, $0.134 \pm 0.048$ and $0.897 \pm 0.134$ when $L$. (V.) braziliensis antigen was used, and $0.957 \pm 0.423,0.137 \pm 0.076$ and $0.418 \pm 0.204$ when $L$. (L.) chagasi antigen was used. No significant difference in mean OD values for the detection of IgG was observed between antigens $(p=0.790)$ (Fig. 1 and 2). 


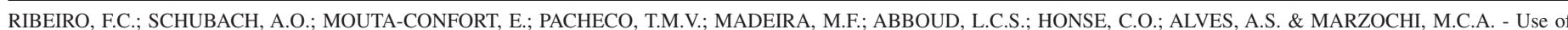
ELISA employing homologous and heterologous antigens for the detection of IgG and subclasses (IgG1 and IgG2) in the diagnosis of canine visceral leishmaniasis. Rev. Inst. Med. Trop. Sao Paulo, 53(5): 283-9, 2011
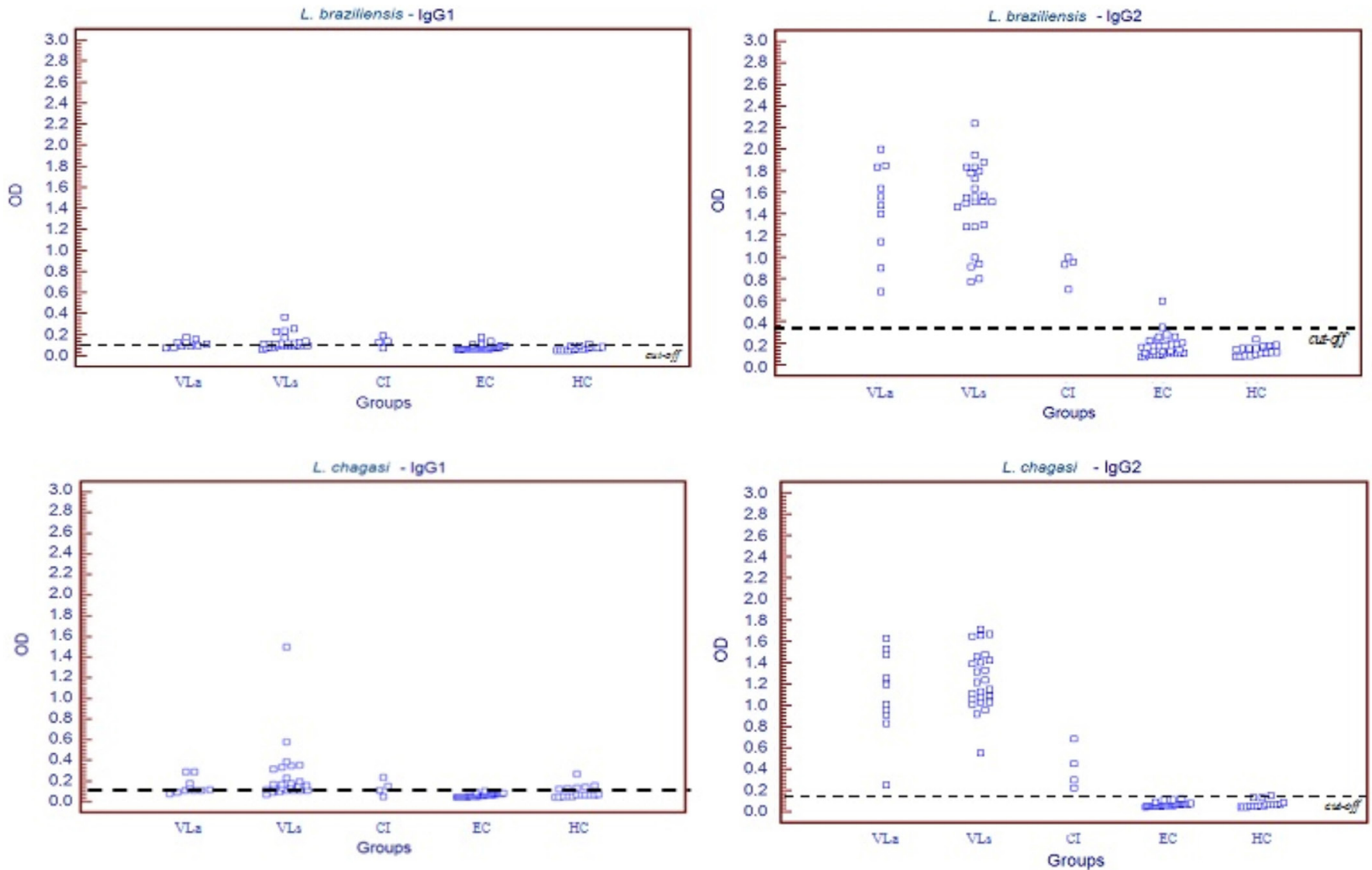

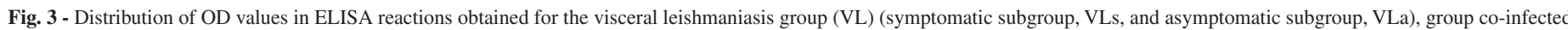

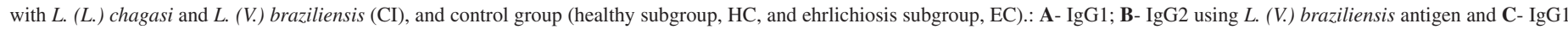
and D- IgG2 using L. (L.) chagasi antigen.

In the $\mathrm{HC}$ and EC control groups, low mean OD values and standard deviations were obtained for the detection of IgG (Fig. 1 and 2), IgG1 and IgG2 when $L$. (V.) braziliensis $(0.126 \pm 0.031,0.076 \pm 0.023$, and $0.158 \pm 0.088$, respectively) and $L$. (L.) chagasi antigens $(0.111 \pm 0.076$, $0.073 \pm 0.039$, and $0.069 \pm 0.024)$ were used. In the EC group, IgG1 was detected in $29.0 \%$ and $14.3 \%$ of serum samples tested with $L$. (V.) braziliensis and $L$. (L.) chagasi antigen, respectively.

The distribution of OD values in ELISA reactions obtained for IgG1 and IgG2 for all groups are shown in Fig. 3.

\section{DISCUSSION}

In the present study, we evaluated the detection of $\operatorname{IgG}$ and its subclasses by ELISA comparing L. (L.) chagasi (homologous) and $L$. (V.) braziliensis (heterologous) antigens in order to improve the performance of the assay for the diagnosis of AVL in symptomatic or asymptomatic naturally infected dogs.

Higher mean OD values were obtained for the detection of $\mathrm{IgG}$, IgG1 and IgG2 in sera from dogs with AVL when $L$. (L.) chagasi antigen was employed. The use of homologous antigen for the diagnosis of leishmaniasis has been reported to provide the best results for both canine $^{4}$ and human ${ }^{2,21}$ AVL, as well for canine ${ }^{46}$ and human ${ }^{6}$ American cutaneous leishmaniasis ${ }^{3}$. BADARÓ et al. ${ }^{3}$ demonstrated that the use of antigens from Leishmania sp. isolated from the same area where the cases occurred increased the accuracy of the assay. DA COSTA et al. ${ }^{12}$ observed no significant differences in the sensitivity of IIF reactions for the diagnosis of canine AVL when different Leishmania species were used as antigens.

Overlapping transmission of AVL caused by L. (L.) chagasi and American cutaneous leishmaniasis caused by L. (V.) braziliensis has been observed in various regions of the Municipality of Rio de Janeiro ${ }^{39,40}$. In the group of dogs co-infected with $L$. (V.) braziliensis and $L$. (L.) chagasi, similar mean OD values for the detection of IgG were obtained with the two antigens, a finding suggesting a balance in the humoral immune response. Since euthanasia is not indicated for dogs infected with $L$. (V.) braziliensis from areas with overlapping transmission of the two species, ELISA employing both antigens could be used to select dogs for parasitological investigation ${ }^{46}$.

Some investigators have reported an association between the immune response (Th1/Th2) and IgG subclasses in dogs infected with L. (L.) infantum ${ }^{7,15}$. However, other authors do not agree that the IgG2 or IgG1 subclass is a marker of a Th1 or Th2 immune response in dogs, respectively ${ }^{14,33}$. This discrepancy might be explained by the different antisera used. 


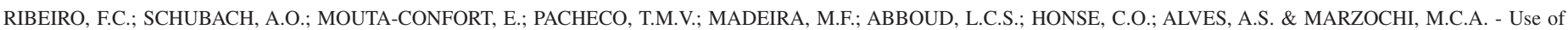

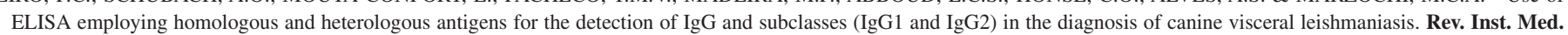
Trop. Sao Paulo, 53(5): 283-9, 2011.

AVL is frequently associated with a marked specific humoral response and anti-Leishmania IgG subclass levels have been suggested to be markers of disease susceptibility and resistance, with IgG1 being associated with the development of the disease and IgG2 with asymptomatic infection ${ }^{7,9,15,25,43,49}$. However, this association was not observed by QUINELL et al. (2003) when using monoclonal antisera.

In the present study, mean OD values obtained for the IgG, IgG1 and $\mathrm{IgG} 2$ reactions were higher in symptomatic (group VLs) than in asymptomatic dogs (group VLa), a finding also reported by INIESTA et al. ${ }^{22}$. IgG2 was the most seroprevalent subclass in both subgroups, with a seroprevalence close to that of $\mathrm{IgG}$, a fact that did not increase the performance of the diagnostic test. These results agree with similar studies involving dogs infected with L. infantum $^{7,10,20,38,53}$.

The seroprevalence of IgG1 was relatively low in infected animals but slightly higher in symptomatic (group VLs) dogs when compared to asymptomatic animals (group VLa). This low seroprevalence of IgG1 indicates its limited use for the diagnosis of AVL. The limitation of IgG1 in the diagnosis of canine AVL has been suggested previously ${ }^{38}$. Other investigators proposed that this subclass predominates in dogs infected with $L$. (L.) chagasi or $L$. (L.) infantum ${ }^{37,44}$, or that $I g G 1$ levels are only elevated in the presence of signs of visceral leishmaniasis ${ }^{49}$.

In the present study, the correlation between OD values for the detection of $\mathrm{IgG}$ and $\mathrm{IgG} 2$ was high and significant. However, the correlation of OD values for IgG or IgG2 with IgG1 was low. LEANDRO et al. ${ }^{25}$, studying symptomatic infected dogs, also observed high levels of $\mathrm{IgG} 2$, with a strong correlation between $\mathrm{IgG}$ and $\mathrm{IgG} 2$. In agreement with these findings, there was no significant difference between the AUCs of IgG and IgG2, whereas a significant difference was observed when comparing each marker to the AUC of IgG1.

Canine ehrlichiosis is an important differential diagnosis of AVL due to the similar clinical findings and high prevalence of dogs infected with E. canis in Rio de Janeiro ${ }^{27}$. Serology has been used to differentiate the two infections ${ }^{48}$. LLERA et al. ${ }^{26}$ observed no cross-reaction between sera of dogs infected with $E$. canis and $L$. infantum. However, we observed cross-reactivity in IIF and in ELISA (IgG1). Similar findings have been reported by FERREIRA et al. ${ }^{18}$.

In conclusion, the present study suggests that IgG ELISA using $L$. (L.) chagasi antigen yielded the best results for the diagnosis of AVL, permitting the discrimination between cases of AVL and ehrlichiosis in dogs. However, the $100 \%$ positivity of IgG observed for serum samples from dogs of the VL group might be related to the selection criterion adopted in this study, i.e., dogs testing seropositive by IIF. We suggest a comparative study of IIF and IgG ELISA using $L$. (L.) chagasi antigen for the evaluation of dogs from AVL-endemic areas under field conditions.

\section{RESUMO}

\section{A utilização do ELISA empregando antígenos homólogos e heterólogos para a detecção de IgG e subclasses (IgG1 e IgG2) no diagnóstico de Leishmaniose Visceral Canina}

A imunofluorescência indireta é o método recomendado para o diagnóstico de leishmaniose visceral em cães, entretanto, a acurácia dessa técnica é baixa e seu uso em grande escala é limitado. Uma vez que o ELISA não apresenta essas limitações, essa técnica poderia ser uma opção para a detecção de IgG ou subclasses IgG1 e IgG2 específicas. A ehrlichiose canina é um importante diagnóstico diferencial de Leishmaniose Visceral Americana (LVA). O presente estudo comparou o ELISA usando antígenos de Leishmania chagasi e Leishmania braziliensis para a detecção de IgG e subclasses anti-Leishmania em amostras de soro de 37 cães naturalmente infectados com L. chagasi (LVA) e em amostras de quatro cães co-infectados $(\mathrm{CI})$. A ocorrência de reatividade cruzada foi investigada em amostras de soro controle de 17 animais saudáveis (HC) e 35 de infectados por Ehrlichia canis (EC). A média de densidade óptica obtida para a detecção de IgG foi significantemente maior quando o antígeno de L. chagasi foi usado e também mais elevada no subgrupo LVs (sintomático) quando comparado ao subgrupo LVa (assintomático). A correlação entre IgG e IgG1 foi baixa. O presente resultado sugere que ELISA IgG empregando antígeno homólogo, produz os melhores resultados, permitindo o diagnóstico de infecção assintomática por $L$. chagasi e a discriminação entre casos de LVA e ehrlichiose em cães.

\section{ACKNOWLEDGMENTS}

We thank the Instituto Municipal de Medicina Veterinária Jorge Vaitsman and the veterinarian Bianca Pellegrinetti Junqueira de Andrade for help with the collection of the control sera, and Centro de Controle de Zoonoses Paulo Darcoso Filho and Programa de Controle das Leishmanioses da Secretaria Municipal de Saúde do Rio de Janeiro for help with the identification of the animals studied. The study was conducted according to ethical guidelines and was approved by the Ethics Committee for the Use of Animals (CEUA/FIOCRUZ/P-0276-05).

This study was partially supported by Programa de Apoio a Pesquisa Estratégica em Saúde (PAPES IV). A. Schubach and T. Schubach are the recipients of fellowships from Conselho Nacional de Desenvolvimento Científico e Tecnológico (CNPq).

\section{REFERENCES}

1. Alvar J, Cañavate C, Molina R, Moreno J, Nieto J. Canine leishmaniasis. Adv Parasitol. 2004;57:1-88

2. Badaró R, Reed SG, Carvalho EM. Immunofluorescent antibody test in American visceral leishmaniasis: sensitivity and specificity of different morphological forms of two Leishmania species. Am J Trop Med Hyg. 1983;32:480-4.

3. Badaró R, Reed SG, Barral A, Orge G, Jones TC. Evaluation of the micro enzyme-linked immunosorbent assay (ELISA) for antibodies in American visceral leishmaniasis: antigen selection for detection of infection-specific responses. Am J Trop Med Hyg. 1986;35:72-8.

4. Baleeiro CO, Paranhos-Silva M, dos Santos JC, Oliveira GG, Nascimento EG, de Carvalho LP, et al. Montenegro's skin reactions and antibodies against different Leishmania species in dogs from a visceral leishmaniosis endemic area. Vet Parasitol. 2006;139:21-8

5. Barbosa-De-Deus R, Dos Mares-Guia ML, Nunes AZ, Costa KM, Junqueira RG, Mayrink W, et al. Leishmania major-like antigen for specific and sensitive serodiagnosis of human and canine visceral leishmaniasis. Clin Diagn Lab Immunol. 2002;9:1361-6.

6. Barroso-Freitas A, Passos SR, Mouta-Confort E, Madeira MF, Schubach AO, Santos GP, et al. Accuracy of an ELISA and indirect immunofluorescence for the laboratory diagnosis of American tegumentary leishmaniasis. Trans R Soc Trop Med Hyg. 2009;103:383-9. 


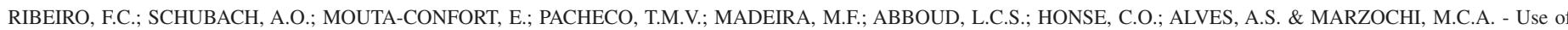
ELISA employing homologous and heterologous antigens for the detection of IgG and subclasses (IgG1 and IgG2) in the diagnosis of canine visceral leishmaniasis. Rev. Inst. Med. Trop. Sao Paulo, 53(5): 283-9, 2011.

7. Bourdoiseau G, Bonnefont C, Hoareau E, Boehringer C, Stolle T, Chabanne L. Specific $\mathrm{IgG1}$ and IgG2 antibody and lymphocyte subset levels in naturally Leishmania infantum-infected treated and untreated dogs. Vet Immunol Immunopathol. 1997;59:21-30.

8. Braga MD, Coelho IC, Pompeu MM, Evans TG, MacAullife IT, Teixeira MJ, et al. Controle do calazar canino: comparação dos resultados de um programa de eliminação rápida de cães sororreagentes por ensaio imuno-enzimático com outro de eliminação tardia de cães sororreagentes por teste de imunofluorescência indireta de eluato de papel filtro. Rev Soc Bras Med Trop. 1998;31:419-24.

9. Cardoso L, Schallig HD, Cordeiro-da-Silva A, Cabral M, Alunda JM, Rodrigues M. Anti-Leishmania humoral and cellular immune responses in naturally infected symptomatic and asymptomatic dogs. Vet Immunol Immunopathol. 2007;117:35-41.

10. Cordeiro-da-Silva A, Cardoso L, Araújo N, Castro H, Tomás A, Rodrigues M, et al. Identification of antibodies to Leishmania silent information regulatory 2 (SIR2) protein homologue during canine natural infections: pathological implications. Immunol Lett. 2003;86:155-62.

11. Courtenay O, Quinnell RJ, Garcez LM, Shaw JJ, Dye C. Infectiousness in a cohort of Brazilian dogs: why culling fails to control visceral leishmaniasis in areas of high transmission. J Infect Dis. 2002;186:1314-20.

12. Da Costa CA, Genaro O, de Lana M, Magalhães PA, Dias M, Michalick MS, et al. Leishmaniose visceral canina: avaliação da metodologia sorológica utilizada em inquéritos epidemiológicos. Rev Soc Bras Med Trop. 1991;24:21-5.

13. Da Costa-Val AP, Cavalcanti RR, de Figueiredo Gontijo N, Michalick MS, Alexander B, Williams P, et al. Canine visceral leishmaniasis: relationships between clinical status, humoral immune response, haematology and Lutzomyia (Lutzomyia) longipalpis infectivity. Vet J. 2007;174:636-43.

14. Day MJ. Immunoglobulin G subclass distribution in canine leishmaniosis: a review and analysis of pitfalls in interpretation. Vet Parasitol. 2007;147: 2-8.

15. Deplazes P, Smith NC, Arnold P, Lutz H, Eckert J. Specific IgG1 and IgG2 antibody responses of dogs to Leishmania infantum and other parasites. Parasite Immunol. 1995;17:451-8.

16. Dye C. The logic of visceral leishmaniasis control. Am J Trop Med Hyg. 1996;55:12530.

17. Edrissian GH, Darabian P. A comparison of enzyme-linked immunosorbent assay and indirect fluorescent antibody test in the serodiagnosis of cutaneous and visceral leishmaniasis in Iran. Trans R Soc Trop Med Hyg. 1979;73:289-92.

18. Ferreira EC, De Lana M., Carneiro M, Reis AB, Paes DV, Da Silva ES, et al. Comparison of serological assays for the diagnosis of canine visceral leishmaniasis in animals presenting different clinical manifestations. Vet. Parasitol. 2007;146:235-41.

19 Fisa R, Gállego M, Castillejo S, Aisa MJ, Serra T, Riera C, et al. Epidemiology of canine leishmaniosis in Catalonia (Spain) the example of the Priorat focus. Vet Parasitol. 1999;83:87-97.

20. Harrus S, Waner T, Strauss-Ayali D, Bark H, Jongejan F, Hecht G, et al. Dynamics of IgG1 and IgG2 subclass response in dogs naturally and experimentally infected with Ehrlichia canis. Vet Parasitol. 2001;99:63-71.

21. Hommel M, Peters W, Ranque J, Quilici M, Lannotte G. The micro-ELISA technique in the serodiagnosis of visceral leishmaniasis. Ann Trop Med Parasitol. 1978;72:21318.

22. Iniesta L, Gállego M, Portús M. Immunoglobulin G and E responses in various stages of canine leishmaniosis. Vet Immunol Immunopathol. 2005;103:77-81.

23. Jones TC, Hunt RD, King NW. Moléstias causadas por protozoários In: Jones TC, Hunt RD, King NW. Patologia veterinária. 6ª ed. São Paulo: Manole; 2000. p. 559610
24. Junqueira Pedras M, Orsini M, Castro M, Passos VM, Rabello A. Antibody subclass profile against Leishmania braziliensis and Leishmania amazonensis in the diagnosis and follow-up of mucosal leishmaniasis. Diagn Microbiol Infect Dis. 2003;47:477-85.

25. Leandro C, Santos-Gomes GM, Campino L, Romão P, Cortes S, Rolão N, et al. Cell mediated immunity and specific IgG1 and IgG2 antibody response in natural and experimental canine leishmaniosis. Vet Immunol Immunopathol. 2001;79:273-84.

26. Llera JL, López García ML, Martín Reinoso E, De Vivar González R. Differentia serological testing by simultaneous indirect immunofluorescent antibody test in canine leishmaniosis and ehrlichiosis. Vet Parasitol. 2002;109:185-90.

27. Macieira DB, Messick JB, Cerqueira AD, Freire IM, Linhares GF, Almeida NK, et al. Prevalence of Ehrlichia canis infection in thrombocytopenic dogs from Rio de Janeiro, Brazil. Vet Clin Pathol. 2005;34:44-48.

28. Madeira M F, Schubach AO, Schubach TMP, Leal CA, Marzochi CA. Identification of Leishmania (Leishmania) chagasi isolated from health skin of symptomatic and asymptomatic dogs seropositive for Leishmaniasis in the Municipality of Rio de Janeiro, Brazil. Braz J Infect Dis. 2004;8:440-4

29. Madeira MF, Schubach AO, Schubach TM, Pereira SA, Figueiredo FB, Baptista C, et al. Post mortem parasitological evaluation of dogs seroreactive for Leishmania from Rio de Janeiro, Brazil. Vet Parasitol. 2006;138:366-70.

30. Mancianti F, Falcone ML, Gianneli C, Poli A. Comparison between an enzyme-linked immunosorbent assay using a detergent-soluble Leishmania infantum antigen and indirect immunofluorescence for the diagnosis of canine leishmaniosis. Vet. Parasitol. 1995;59:13-21.

31. Manzillo VF, Cappiello S, Oliva G. Tick-transmitted diseases in dogs: clinic pathological findings. Parassitologia. 2006;48:135-6.

32. Marzochi MC, Sabroza PC, Toledo LM, Marzochi KB, Tramontano NC, Rangel Filho FB. Leishmaniose visceral na cidade do Rio de Janeiro-Brasil. Cad Saúde Públ. 1985;1: 5-17.

33. Mazza G, Duffus WP, Elson CJ, Stokes CR, Wilson AD, Whiting AH. The separation and identification by monoclonal antibodies of dog IgG fractions. J Immunol Methods. 1993;161:193-203.

34. Mazza G, Whiting AH, Day MJ, Duffus WPH. Development of an enzyme-linked immunosorbent assay for the detection of IgG subclasses in the serum of normal and diseased dogs. Res Vet Sci. 1994;57:133-9.

35. Mazza G, Whiting AH, Day MJ, Duffus WPH. Preparation of monoclonal antibodies specific for the subclasses of canine IgG. Res Vet Sci. 1994;57:140-5.

36. McDade JE. Ehrlichiosis - a disease of animals and humans. J Infect Dis 1990;161:609-17.

37. Mendes CO, De Sousa EP, Borja-Cabrera GP, Batista LM, Santos MA, Parra LE, et al. IgG1/IgG2 antibody dichotomy in sera of vaccinated or naturally infected dogs with visceral leishmaniosis. Vaccine. 2003;21:2589-97.

38. Mettler M, Grimm F, Capelli G, Camp H, Deplazes P. Evaluation of Enzyme-Linked Immunosorbent Assays, an Immunofluorescent-antibody test, and two rapid tests (Immunochromatographic-Dipstick and Gel Tests) for serological diagnosis of symptomatic and asymptomatic Leishmania infections in dogs. J Clin Microbiol. 2005;43:5515-9.

39. Ministério da Saúde. Manual de vigilância e controle da leishmaniose visceral. Brasília: Ministério da Saúde, 2006. 120 p.

40. Ministério da Saúde. Manual de vigilância e controle da leishmaniose tegumentar americana. Brasília: Ministério da Saúde; 2007. 182 p.

41. Molina R, Amela C, Nieto J, San-Andrés M, González F, Castillo JA, et al. Infectivity of dogs naturally infected with Leishmania infantum to colonized Phlebotomus perniciosus. Trans R Soc Trop Med Hyg. 1994;88:491-3. 


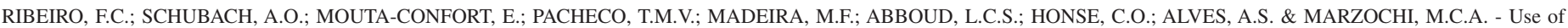

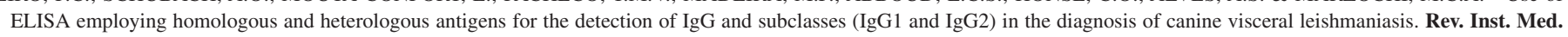
Trop. Sao Paulo, 53(5): 283-9, 2011.

42. Moreira SM, Bastos CV, Araújo RB, Santos M, Passos LMF. Retrospective study (1998-2001) on canine ehrlichiosis in Belo Horizonte, MG, Brazil. Arq Bras Med Vet Zootec. 2003;55:141-7.

43. Nakhaee A, Taheri T, Taghikhani M, Mohebali M, Salmanian AH, Fasel N, et al. Humoral and cellular immune responses against Type I cysteine proteinase of Leishmania infantum are higher in asymptomatic than symptomatic dogs selected from a naturally infected population. Vet Parasitol. 2004;119:107-23.

44. Quinnell RJ, Courtenay O, Garcez LM, Kaye PM, Shaw MA, Dye C, et al. IgG subclass responses in a longitudinal study of canine visceral leishmaniasis. Vet Immunol Immunopathol. 2003;91:161-8.

45. Reis AB, Teixeira-Carvalho A, Vale AM, Marques MJ, Giunchetti RC, Mayrink W, et al. Isotype patterns of immunoglobulins: hallmarks for clinical status and tissue parasite density in Brazilian dogs naturally infected by Leishmania (Leishmania) chagasi. Vet Immunol Immunopathol. 2006;112:102-16.

46. Ribeiro FC, Schubach AO, Mouta-Confort E, Schubach TM, Madeira MF, Marzochi MC. Use of ELISA employing Leishmania (Viannia) braziliensis and Leishmania (Leishmania) chagasi antigens for the detection of IgG and IgG1 and IgG2 subclasses in the diagnosis of American tegumentary leishmaniasis in dogs. Vet Parasitol. 2007;148:200-6.

47. Rikihisia Y. The tribe Ehrlichiae and ehrlichial diseases. Clin Microbiol Rev. 1991;4:286-308.

48. Sanchez Visconti G, Tesouro Diez MA, editors. Ehrlichiosis. Canis et felis (San Román, Madrid). 2001; 51:49-56
49. Solano-Gallego L, Riera C, Roura X, Iniesta L, Gallego M, Valladares JE, et al. Leishmania infantum-specific $\mathrm{IgG}, \mathrm{IgG} 1$ and $\mathrm{IgG} 2$ antibody responses in healthy and ill dogs from endemic areas. Evolution in the course of infection and after treatment Vet Parasitol. 2001;96:265-76.

50. Souza MA, Da Silva AG, Afonso-Cardoso SR, Favoreto Júnior SF, Ferreira MS Perfil de isotipos de imunoglobulinas e subclasses de $\mathrm{IgG}$ na leishmaniose tegumentar americana. Rev Soc Bras Med Trop. 2005;38:137-41.

51. Tesh R. Control of zoonotic visceral leishmaniasis: is it time to change strategies? Am J Trop Med Hyg. 1995;52:287-92.

52. Tizard IR. Anticorpos forma solúvel de RBC. In: Tizard IR. Imunologia veterinária,

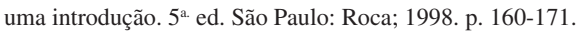

53. Vercammen F, Fernandez-Perez FJ, Amo CD, Alunda JM. Follow-up of Leishmania infantum naturally infected dogs treated with allopurinol: immunofluorescence antibody test, ELISA and Western blot. Acta Trop. 2002;84:175-81.

54. Voller A, Bartlett A, Bidwell DE, Clarck MF, Adams AN. The detection of viruses by enzyme-linked immunosorbent assay (ELISA). J Gen Virol. 1976;33:165-7.

55. Woody BJ, Hoskins JD. Ehrlichial diseases of dogs. Vet Clin North Am Small Anim Pract. 1991;21:75-98.

Received: 24 August 2009

Accepted: 5 August 2011 


\section{Revista do Instituto de Medicina Tropical de São Paulo on line.}

Publications from 1990 to the present data are now available on:

http://www.scielo.br/rimtsp

PAST ISSUES 1959-1989 (PDF)

www.imt.usp.br/portal/

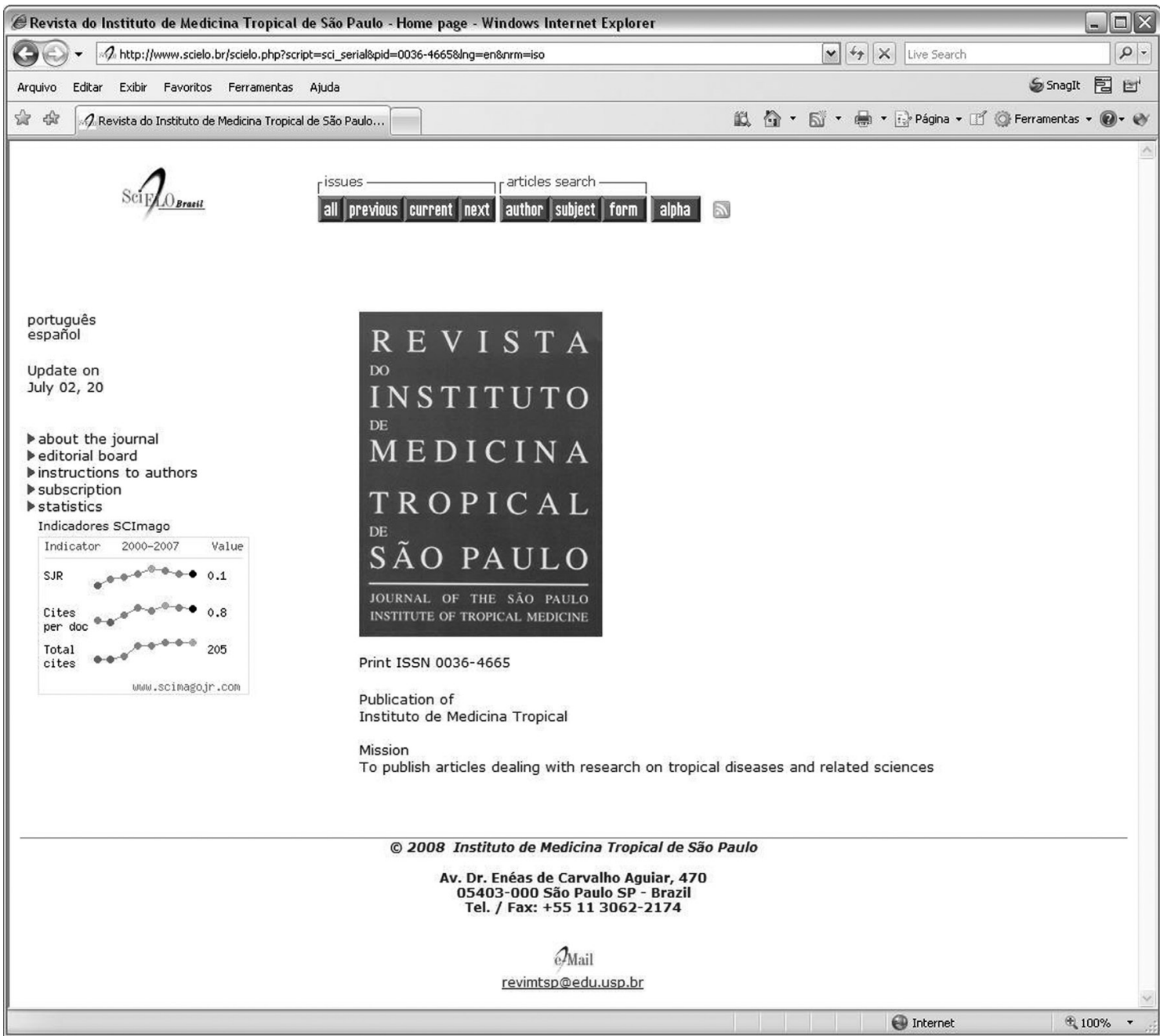

SciELO - The Scientific Electronic Library OnLine - SciELO is an electronic virtual covering a selected collection of Brazilian scientific journals.

The library is an integral part of a project being developed by FAPESP - Fundação de Amparo à Pesquisa do Estado de São Paulo, in partnership with BIREME - the Latin American and Caribbean Center on Health Sciences Information.

SciELO interface provides access to its serials collection via an alphabetic list of titles or a subject index or a search by word of serial titles, publisher names, city of publication and subject.

The interface also provides access to the full text of articles via author index or subject index or a search form on article elements such as author names, words from title, subject and words from full text.

FAPESP/BIREME Project on Scientific Electronic Publications Latin American and Caribbean Center on Health Sciences Information

Rua Botucatu 862 - 04023-901 São Paulo, SP - Brazil

Tel. (011) 5576-9863

scielo@bireme.br 